\title{
COMUNICAÇÃO
}

\section{COLETA DE SANGUE EM PAPEL DE FILTRO PARA FINS DE INQUÉRITOS SOROEPIDEMIOLÓGICOS *}

\author{
M. Carolina Soares Guimarães
}

\section{Material necessário}

- retângulos de papel de filtro Whatman no 1, medindo $7,5 \times 3 \mathrm{~cm}$, intercalados por retângulos do mesmo tamanho de celofane;

- lancetas descartáveis;

- algodão;

- álcool absoluto;

- papel de alumínio;

- saco plástico;

- recipiente de isopor;

- fita crepe ou esparadrapo.

\section{Técnica}

- Delimitar com lápis no papel de filtro 2 círculos de $2,26 \mathrm{~cm}$ de diâmetro (com $4 \mathrm{~cm}^{2}$ de área). No canto superior direito, deixar espaço para ser assinalado a lápis o nome, a data e o local da coleta;

- Juntar 10 (dez) destes retàngulos intercalando-os com uma folha do mesmo tamanho de papel celofane formando assim um caderno. Grampear as folhas na extremidade esquerda;

- Limpar bem o dedo anular da mão esquerda da pessoa de quem se vai coletar sangue com algodão embebido em álcool absoluto;

\footnotetext{
* Orientação solicitada e divulgada pela Sociedade Brasileira de Medicina Tropical.
}

Laboratório de Soroepidemiologia, Instituto de Medicina Tropical de São Paulo/Departamento de Medicina Preventiva, Faculdade de Medicina, USP.
- Lancetar a porção distal interna da polpa digital da 3a falange;

- Limpar com uma porção de algodão seco a primeira gota que se forma;

- Apertar o dedo anular com movimentos sucessivos indo da base à porção distal forçando a saida do sangue pelo corte;

- Aproximar a área delimitada do papel de filtro da gota de sangue e deixar que esta seja absorvida pelo papel. Recobrir com uma única camada de sangue toda a área delimitada verificando se o verso do papel está igualmente embebido evitando porém que fique ensopado;

- Repetir na segunda área delimitada do papel;

- Em crianças de até um ano de idade a coleta pode ser feita lancetando-se o calcanhar e observando-se os mesmos cuidados de assepsia;

- Deixar os cadernos secarem à sombra em lugar arejado por 60 minutos;

- Envolver um conjunto de 10 cadernos em papel de alumínio, dobrando bem as bordas;

- Colocar todos os pacotes em saco plástico resistente, fechando-o bem com esparadrapo ou fita crepe;

- Se a distância até o centro processador for grande ou se envolver viagem por regiōes de temperatura elevadas, colocar o conjunto em recipiente de isopor bem fechado por fita crepe;

- A eluição de cada círculo de $4 \mathrm{~cm}^{2}$ com $0,25 \mathrm{ml}$ de eluente resultará em diluição aproximadamente igual a $1: 5$. 